\title{
The increase of crystal growing rate without damaging the smoothness of interface border
}

\author{
V.N.Kanishchev \\ Institute for Single Crystals, STC "Institute for Single Crystals" \\ National Academy of Sciences of Ukraine, \\ 60 Lenin Ave., Kharkiv 61001, Ukraine
}

Received December 3, 2012

\begin{abstract}
This paper provides literature data on non-stationary crystallization of binary melt, making it possible to put forward a hypothesis about a fluctuation mechanism of the structure transitions on the interface surface. Another argument for this hypothesis is the authors' observation results of the front crystallization at growing a sapphire crystal by horizontal directed crystallization. It has been suggested that it will be possible to grow crystals with a smooth interface border faster at a variable rate of crystallization rather than at a constant one.
\end{abstract}

Приведены литературные данные по нестационарной кристаллизации бинарного расплава, позволяющие выдвинуть гипотезу о флуктуационном механизме структурных переходов на межфазной поверхности. В пользу выдвинутой гипотезы свидетельствуют результаты проведенных авторами наблюдений за фронтом кристаллизации при выращивании сапфира методом горизонтальной направленной кристаллизации. Высказано предположение, что, кристаллизуя расплав с переменной скоростью, кристалл с гладкой границей раздела удастся вырастить в целом быстрее, чем проводя кристаллизацию в стационарном режиме.

It is known that an exceeding of the critical crystal-growing rate results in damaging the smoothness of crystallization front (CF), which decreases the quality of a crystal [1]. This phenomenon also known as breakdown can be explained within a framework of concentration overcooling conception $(\mathrm{CO})$.

Unlike almost forgotten but more profound Mallinz and Sekerka theory [2], CO criterion structured over half a century ago by Tiller at alias is still an unalterable authority for modern crystal growing technologists.

We suggest an idea that may allow increasing the rate of crystal growing with a smooth CF. The prerequisite of this idea was the influence of surface tension on the relationship between the impurity density in melt $\mathrm{C}_{0}$ and a reciprocal value of the critical crystallization rate $V_{c r}$. This influence
[3] becomes apparent in shifting $\mathrm{C}_{0}\left(1 / V_{c r}\right)$ graph towards the concentration axis. However, the literature does not offer any experimental proof of this conclusion.

According to [4], the main reason of the experimental errors in plotting $C_{0}\left(1 / V_{c r}\right)$ graph is a popular notion that the pulling $w$ and the crystallization $V$ rates are the same things. We perceive the crystal pulling as any temperature redistribution in crystalmelt system, resulting in crystal growing.

In order to obtain a most accurate $C_{0}\left(1 / V_{c r}\right)$ dependence, Morris and Weingard [5] carried out the following experiment. They had the melt crystallized by moving the heater along the growing crystal with acceleration $\sim 0.1 \mu \mathrm{m} / \mathrm{min}^{2}$ so that $w$ and $V$ were almost equal. However, the $C_{0}\left(1 / V_{c r}\right)$ dependence they obtained (Fig. 2 straight line 1) did not hold neither $\mathrm{CO}$ criterion (line 2) nor its improved analog (line3). 


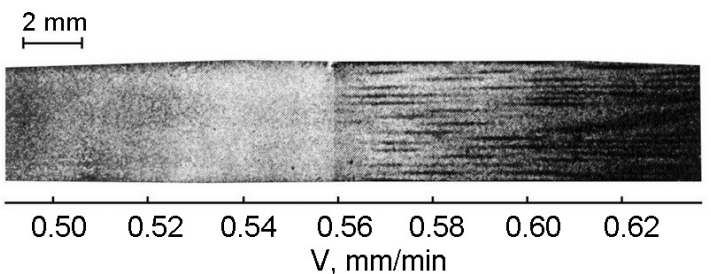

Fig. 1 Longitudinal cut of $\mathrm{Pb}-\mathrm{Sb}$ crystal (175ppm) grown by means of a slow accelerating heater. The interface border lost its smoothness (breakdown moment) at a growing rate $V=0.56 \mathrm{~mm} / \mathrm{min} \mathrm{[5].}$

They explained the reason of such an incongruity (alas without referring to Mallinz and Sekerka theory) by the presence of residual impurity, forgetting the fact that residual impurity reveals itself in distorting $C_{0}\left(1 / V_{c r}\right)$ graph but not in shifting it towards the inverse rate. Indeed, the decrease of controlled impurity $C_{0}$ will lead to the increase of $V_{c r}$ until the uncontrolled impurity begins to count. In that case, $V_{c r}$ will not depend on $C_{0}$ and the graph will be a vertical line.

The solution to this problem can be found in the paper of the same authors [5]. While growing a crystal at a constant rate that leads to a cellular structure (Fig. 3a), they sharply doubled the growing rate, which according to the literature [1] should almost halve the size of the cells. Nevertheless, islets of smaller cells began to appear only in $10 \mathrm{~min}$ after the change of the rate and their area grew with time (Fig. 3b).

The authors [5] explained this phenomenon by some special stability of cellular structure. It is strange that they did not take into account the heterophase fluctuation theory that is quite popular in solidification science. The explanation suggests itself. It is similar to that one which can be found in all textbooks on solidification of melts. The islets of smaller cells will appear and disappear until an isle of a critical size forms in the result of some fluctuation. It took about $10 \mathrm{~min}$ for such a fluctuation to arise. This fluctuation mechanism can govern other transformations at the interface as well as the damage of the smoothness. Thus, we can put forward a hypothesis about a fluctuation nature of structure transitions on the interfacial surface.

Based on this hypothesis the events in the experiment of Morris and Weingard [5] can be interpreted as follows. At first just before the moment of breakdown $(V=0.56 \mathrm{~mm} / \mathrm{min})$ the heater reached Tiller rate (for instance, $V=0.52 \mathrm{~mm} / \mathrm{min}$ ), that is

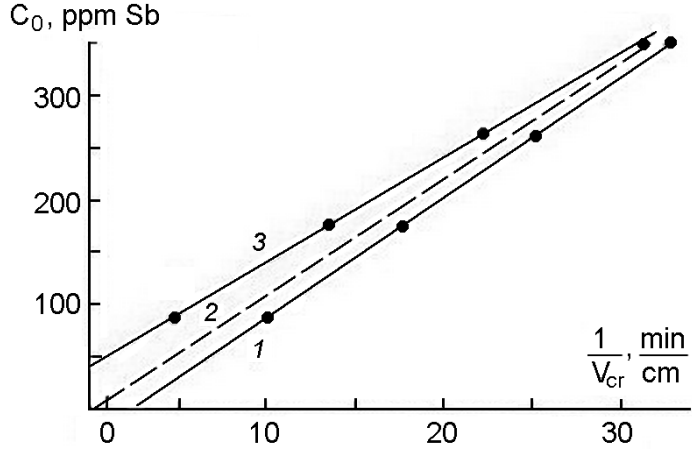

Fig. 2 Antimony concentration CO in lead crystals vs. reciprocal values of the critical rate $V_{c}: 1$ - experiment [5], 2 - calculation by criterion $\mathrm{CO}, 3$ - surface tension calculation.

the rate at which $\mathrm{CO}$ zone forms in melt. Then the heater reached Sekerk rate (for instance, $V=0.54 \mathrm{~mm} / \mathrm{min}$ ), that is the rate at which a smooth CF becomes unstable. After that, while the heater kept moving, the crystal-melt system was getting ready to jump, waiting for a suitable heterophase fluctuation. Therefore it is quite probable that the value plotted on $C_{0}\left(1 / V_{c r}\right)$ graph has nothing to do with either Tiller or Sekerka theory.

It is easy to explain within the framework of this hypothesis that at a rather fast acceleration of the crystal pulling rate a smooth CF becomes a cellular one without being in any transitory structure. Ovsejenko at alias observed through a microscope such an abrupt transition on tin with different impurities at cooling of a half-melted sample [6].

Fig. 4 shows a swift almost uniformly accelerated movement of a smooth CF for a pure sample (line 1) and a rather lagged one for samples with impurities (lines 2 and 3 ). This nonmonotonic dependence of the crystallization rate on time for tin with impurities was explained [6] by a usual accumulation of impurity in front of CF. As for the jump of the rate when a smooth border becomes a cellular one, it is caused at the moment when $\mathrm{CO}$ zone forms in melt.

Even an approximate evaluation gives evidence for the outstanding observations carried out by Ovsejenko at alias. Taking into account the fact that tin-base alloy is rather well known, it is worthwhile analyzing deeply the phenomena discussed in paper [6]. Such an analysis was carried out by means of a numerical modeling of the cooling of a half-melted sample.

We estimated the diffusion of indium in tin melt at pulling a crystal with a rate 


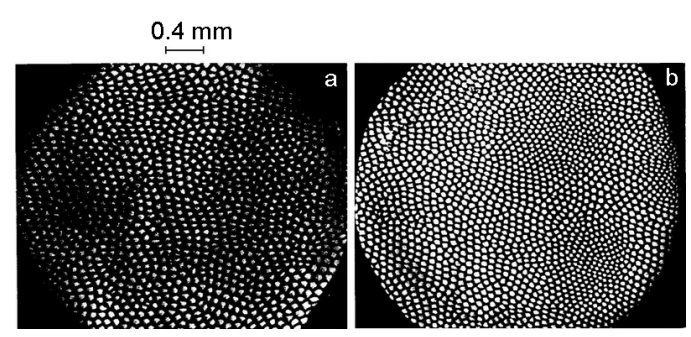

Fig. 3. Structure of Pb-SB crystal (350 ppm) at a growing rate $1.5 \mathrm{~mm} / \mathrm{min}$ (a) and in 13 min after the acceleration of the heater up to $3 \mathrm{~mm} / \mathrm{min}(\mathrm{b})$ [5].

$w(t)$. The simulation of the cooling of the sample was carried out at the following conditions: the pulling rate was uniformly accelerated $w(t)=a t$, temperature gradient on $\mathrm{CF}$, the values of $G(t)$ were selected to enable the curve of crystallization rate $V(t)$ go through the experimental points. The acceleration value a was estimated by the slope of $V(t)$ line for pure tin (Fig4. line 1).

In spite of all the assumptions in the model, the result of the calculation proved to be impressive [7]. CO zone formed in Sn-In melt in the 11 th sec after the beginning of the cooling of the sample. In the 24 th sec the crystallization rate was 5 times higher the critical one, which according to the literature should result in a developed cellular structure. If one takes into account that the interface surface remained smooth for almost $100 \mathrm{sec}$ (Fig.4, line 3) it is difficult to imagine the value that $\mathrm{CO}$ reached in this experiment.

The calculation proved the supposition that the fluctuation mechanism governs the transition from the smooth to the cellular interface surface. It also stimulated a further verification of the supposition on a sapphire-melt system that is much more important from a practical point of view. The Institute of Single Crystals has an advantage in carrying out experiments with sapphire for it has facility to grow it by horizontal directed crystallization that enables the observation of $\mathrm{CF}$ with a video camera.

Sometimes during its growth, sapphire may develop cross strips visible to the naked eye or bubbles that deteriorate its marketable style. Although the bubbles seem to be distributed chaotically, N.P. Katrich managed to see in this chaos some order (Fig.5) that testifies a close relationship between the capture and the cellular formation.

Fig. 6 demonstrates the results of growing a sapphire crystal from Nikolayev alu-

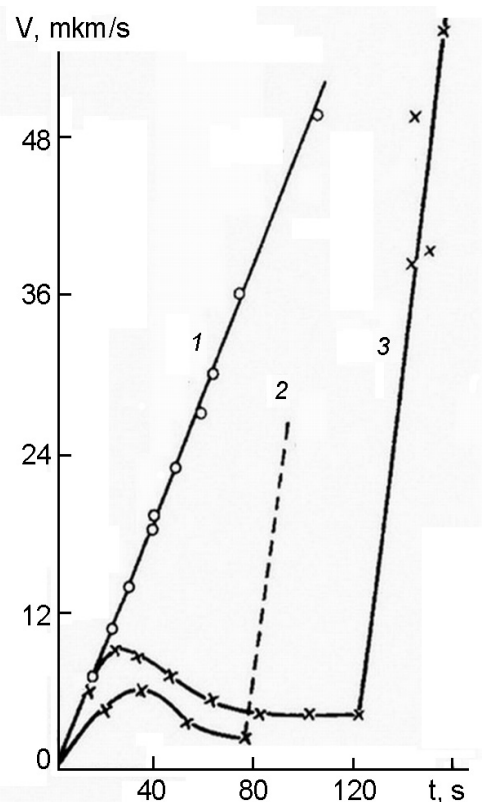

Fig. 4. Time dependence of crystallization rate $\mathrm{V}$ at cooling of partly melted sample: 1 Sn, $2-\operatorname{Sn}+\operatorname{Bi}(1 \%), 3-S n+\ln (1 \%)$ [6].

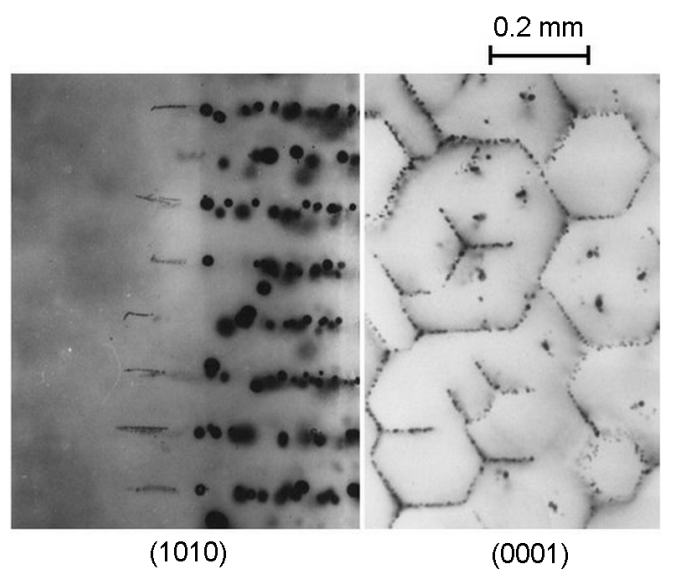

Fig. 5. Bubbles on cell borders in sapphire (photo by N. P. Katrich).

mina with a pulling rate about 5 times higher the conventional one. As we can see, each capture on a longitudinal section of the crystal (Fig. 6a) corresponds to a peak on the videogram of interface border coordinate (Fig. 6b), forming a strict periodicity.

The pulling of a crystal with a variable rate is an obvious remedy against the periodical strips that form under a constant pulling rate. Here is a fact to support this idea.

The last peak on the videogram was not caused by the capture, for the pulling mechanism had been off for several seconds before its appearance. Naturally, CF moved 


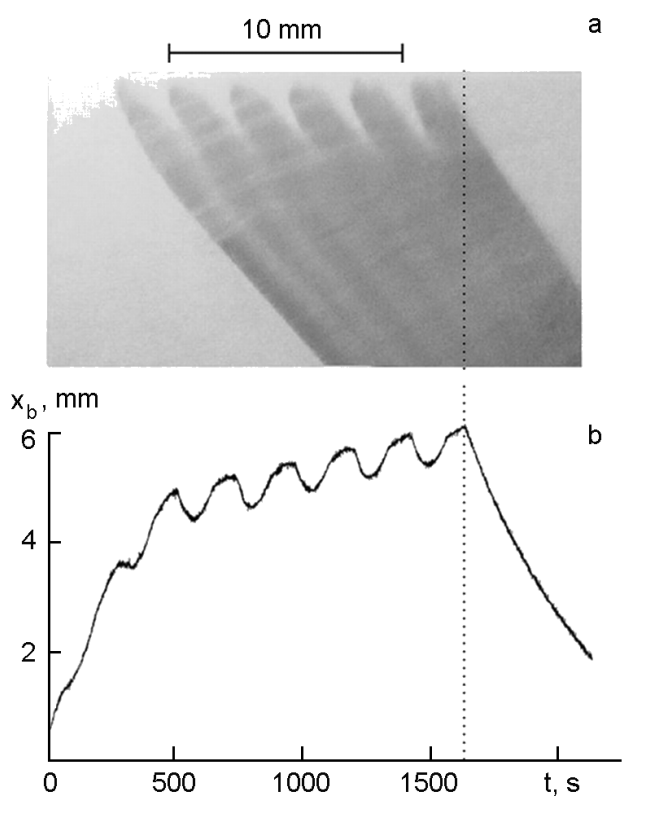

Fig.6. Cross strips formed in sapphire at a growing rate $42 \mathrm{~mm} / \mathrm{h}$ (a) and dependence of the interface border coordinate $x_{b}$ on time $t$ (b); $t=0$ and $t \approx 1640 \mathrm{sec}$ (dot line) - the moments of turning on and off the pulling mechanism, correspondingly.

towards the screen and the coordinate was read off from its edge. CF appeared to cover $4 \mathrm{~mm}$ in less than $500 \mathrm{sec}$, which amounts to $30 \mathrm{~mm} / \mathrm{h}$. The conventional growth rate of sapphire from metallurgical alumina however is no more than $8 \mathrm{~mm} / \mathrm{h}$.

This fact confirms the hypothesis about the fluctuation nature of the transition from a smooth CF to a cellular one. The sapphire-melt system was not allowed to reach the region of the critical growth conditions, which prevented it from the capture since the heterophase fluctuation did not have time to affect the system.

Therefore, the best proof of this hypothesis would be a crystal grown faster at a variable pulling rate with a smooth $\mathrm{CF}$ than at a constant one.

\section{Reference}

1. W.A.Tiller. Crystal Growth from a Melt, in: The Art and Science of Growing Crystals, John Wiley \& Sons, Inc., New York - London (1963).

2. W.A.Tiller., J.W.Rutter, K.A.Jackson, B.Chalmers, Acta Met., 8, 428 (1953).

3. W.W.Mullins, R.F.Sekerka, J. Appl. Phys., 35, 444 (1964).

4. S.V.Barannik, V.N.Kanishchev, Crystallography Rep., 54, 168 (2009).

5. I. R.Morris, W.C.Winegard, J. Cryst. Growth, 5, 361 (1969).

6. D.E.Ovsienko, V.V.Maslov, G.A.Alfintsev, Crystallografiya, 22, 1042 (1977).

7. S.V.Barannik, V.N.Kanishchev, Functional Materials, 17, 224 (2010).

\section{Про можливість більш швидкого вирощування кристалів з розплаву без порушення гладкості міжфазної границі}

\section{B.М.Канішев}

Наведені літературні відомості про нестаціонарну кристалізацію бінарного розплаву, які дозволяють висунути гіпотезу про флуктуаційний механізм структурних переходів на міжфазній поверхні. На користь гіпотези, що запропоновано, свідчать результати спостережень за фронтом кристалізації при вирощуванні сапфіру методом горизонтальної направленої кристалізації. Висловлено припущення, що у разі кристалізації розплаву зі змінною швидкістю, можна швидше отримати кристал з гладкою границею розділу фаз, ніж за умов кристалізації у стаціонарному режимі. 